\title{
Purification, Molecular Cloning, and Expression of the Gene Encoding Fatty Acid 13-Hydroperoxide Lyase from Guava Fruit (Psidium guajava)
}

\author{
Nathalie Tijet ${ }^{a, 1}$, Urs Wäspi ${ }^{b}$, Duncan J.H. Gaskinc ${ }^{c}$, Peter Hunziker ${ }^{d}$, \\ Bernard L. Mullere, Evgeny N. Vulfson ${ }^{c, 2}$, Alan Slusarenko ${ }^{b, 3}$, \\ Alan R. Brash $^{a, *}$, and Ian M. Whitehead ${ }^{e, 4}$ \\ ${ }^{a}$ Department of Pharmacology, Vanderbilt University, Nashville, Tennessee 37232, ${ }^{b}$ Department of Plant Biology, \\ University of Zürich, CH-8008, Switzerland, Institute of Food Research, Department of Macromolecular Sciences, \\ Reading RG6 6BZ, Berkshire, England, 'Department of Biochemistry, University of Zürich, CH-8057, Switzerland, \\ and ${ }^{\mathrm{e}}$ Firmenich S.A., Geneva 8, $\mathrm{CH}-1211$, Switzerland
}

\begin{abstract}
Guava fruit was identified as a particularly rich source of 13-hydroperoxide lyase activity. The enzyme proved stable to chromatographic procedures and was purified to homogeneity. Based on gel filtration and gel electrophoresis, the native enzyme appears to be a homotetramer with subunits of $55 \mathrm{kD}$. Starting with primers based on the peptide sequence, the enzyme was cloned by polymerase chain reaction with $3^{\prime}$ and $5^{\prime}$ rapid amplification of cDNA ends. The sequence shows approximately $60-70 \%$ identity to known 13-hydroperoxide lyases and is classified in cytochrome P450 74B subfamily as CYP74B5. The cDNA was expressed in Escherichia coli (BL21 cells), with optimal enzyme activity obtained in the absence of isopropyl- $\beta$-D-thiogalactopyranoside and $\delta$-aminolevulinic acid. The expressed enzyme metabolized 13(S)-hydroperoxylinolenic acid over 10-fold faster than 13(S)-hydroperoxylinoleic acid and the 9-hydroperoxides of linoleic and linolenic acids. 13(S)-Hydroperoxylinolenic acid was converted to 12 oxododec-9(Z)-enoic acid and 3(Z)-hexenal, as identified by gas chromatography-mass spectrometry. The turnover number with this substrate, with enzyme concentration estimated from the Soret absorbance, was $\approx 2000 / \mathrm{s}$, comparable to values reported for the related allene oxide synthases. Distinctive features of the

${ }^{1}$ Present address: Department of Entomology, Forbes 410, University of Arizona, P.O. Box 210036, Tucson, AZ 85721-0036.

${ }^{2}$ Present address: Institute of Food Research, Norwich Research Park, Colney, Norwich NR4 7UA, England.
\end{abstract}

${ }^{3}$ Present address: RWTH Aachen, Institut für Biologie III (Plant Physiology), Worringerweg, D-52074, Aachen, Germany.

${ }^{4}$ Present address: Firmenich Asia Pte. Ltd, 10 Tuas West Road, Singapore 638377.

*To whom correspondence should be addressed at Dept. of Pharmacology, Vanderbilt University, 23rd Ave. at Pierce, Nashville, TN 37232-6602.

E-mail: alan.brash@mcmail.vanderbilt.edu

Abbreviations: $\delta$-ALA, $\delta$-Aminolevulinic acid; AOS, allene oxide synthase; GC-MS, gas chromatography-mass spectrometry; GPC, gel permeation chromatography; HIC, hydrophobic interaction chromatography; HPL, hydroperoxide lyase; HPLC, high-pressure liquid chromatography; IFC, isoelectric focusing chromatography; IPTG, isopropyl- $\beta$-D-thiogalactopyranoside; LOX, lipoxygenase; NTA, nitrilotriacetic acid; PAGE, polyacrylamide gel electrophoresis; PCR, polymerase chain reaction; RACE, rapid amplification of cDNA ends; RP-HPLC, reversed-phase-high pressure liquid chromatography; SDS, sodium dodecyl sulfate; TFA, trifluoroacetic acid; UV, ultraviolet. guava 13-hydroperoxide lyase and related cytochrome P450 are discussed.

Paper no. L8473 in Lipids 35, 709-720 (July 2000).

The metabolism of fatty acid hydroperoxides [lipoxygenase (LOX) products] involves conversion to epoxides, aldehydes, alcohols, and other derivatives, and these reactions are often catalyzed by cytochrome P450 enzymes. In green plant tissue, the fatty acid hydroperoxide lyase (HPL), an enzyme in the LOX pathway, catalyzes the cleavage of 13- and 9-hydroperoxides of linoleic and linolenic acid into volatile $\mathrm{C}_{6}$ - or $\mathrm{C}_{9}$-aldehydes and $\mathrm{C}_{12^{-}}$or $\mathrm{C}_{9}$-oxoacids, respectively $(1,2)$. The $\mathrm{C}_{6}$ and $\mathrm{C}_{9}$ volatile compounds have a commercial value in the production of "natural" flavor in the food industry, and are potentially important in plant defense against pathogens (3) and pests (4).

The green notes [hexanal, hexan-1-ol, 2(E)-hexenal, 3(Z)hexenal, 2(E)-hexen-1-ol, and 3(Z)-hexen-1-ol (also known as pipol)] are used widely in flavors (particularly fruit) to impart a fresh green character. The synthesis of these compounds starts from free polyunsaturated fatty acids such as linoleic $[9(Z), 12(Z)$-octadecadienoic] and linolenic acids $[9(Z), 12(Z), 15(Z)$-octadecatrienoic]. In nature, these acids are released from cell membranes by lipolytic enzymes after cell damage. Fatty acid 13-hydroperoxides are formed by the action of a specific lipoxygenase (13-LOX), and these are subsequently cleaved by a 13-hydroperoxide lyase (13-HPL) into a $_{6}$-aldehyde and a $\mathrm{C}_{12}$ - $\omega$-oxoacid moiety. The aldehydes can subsequently undergo thermal isomerization and/or be reduced by dehydrogenase enzymes to give the other $\mathrm{C}_{6}$ products mentioned above $(2,5)$.

13-HPL was demonstrated for the first time in banana fruits (6) and subsequently characterized in a number of different plant materials (7-10). The enzyme has been purified to apparent homogeneity from tea leaves (11) and more recently green bell pepper fruits (12) and sunflower (13). 
Cloning of the pepper 13-HPL cDNA confirmed that the enzyme is a member of the cytochrome P450 family of hemoproteins (14). The P450 family is designated as CYP74B. Subsequently, the 13-HPL of Arabidopsis was cloned from published expressed sequence tag sequences and identified as a related cytochrome $\mathrm{P} 450$ (15).

We began the present work with a survey of HPL activities in various commercial fruits and vegetables, and on this basis selected guava fruit as the starting material for further characterization. The 13-HPL activity in guava is substantially higher than in several other well-characterized sources such as bean and pepper. Guava is available on an almost year-round basis, making it an attractive source for the commercial production of fatty acid aldehydes. In the present paper, we describe purification of the 13-HPL from guava fruit, molecular cloning of the cDNA, and expression of the active protein in Escherichia coli.

\section{EXPERIMENTAL PROCEDURES}

Materials. For protein purification, fruits of Psidium guajava from Thailand (bought at a local market in Zürich) were frozen and stored at $-20^{\circ} \mathrm{C}$. For the molecular cloning, immature guava $(\approx 3 \mathrm{~cm}$ in diameter) were collected in Brazil, frozen on dry ice on the same day, and subsequently stored at $-80^{\circ} \mathrm{C}$.

Measurement of 13-HPL activity in fruits and vegetables. The lyase reactions were performed in a four-necked glass vessel equipped with a mechanical stirrer, a dropping funnel topped with a nitrogen bubbler, a thermometer, and a $\mathrm{pH}$ electrode. Guava fruit homogenate $(20 \mathrm{~g})$ prepared in a Waring blender was stirred vigorously under nitrogen at the selected temperature and $\mathrm{pH}$. An aqueous solution of hydroperoxyoctadecadienoic acid or hydroperoxyoctadecatrienoic acid, $20 \mathrm{~g}$, containing $35 \mathrm{~g} / \mathrm{kg}$ hydroperoxide as determined by iodometric titration, was then added. This solution of hydroperoxides consisted of either saponified sunflower oil (serving predominantly as a source of linoleic acid) or saponified linseed oil (linolenic acid) that had been treated with soybean flour (LOX) to form the corresponding 13-hydroperoxides. The formation of hexanal or 3(Z)- and 2(E)-hexenal was monitored by gas chromatography (GC) every $5 \mathrm{~min}$ for the first $15 \mathrm{~min}$, and subsequently every $30 \mathrm{~min}$. The $\mathrm{C}_{6}$-aldehydes were quantified by direct injection of the filtered crude reaction samples onto a 3-m column of Carbowax $10 \%$ on Chromosorb W HP 80/100 mesh (Supelco, Bellefonte, PA) operated isothermally at $100^{\circ} \mathrm{C}$ in a PerkinElmer 2900 gas chromatograph equipped with a flame-ionization detector. The concentrations of hexanal or 3(Z) and 2(E)-hexenal were determined by comparison with an external standard solution of $500 \mathrm{mg} / \mathrm{L}$ hexanal or 2(E)-hexenal in $0.5 \% \mathrm{EtOH} / 99.5 \%$ water solution.

Purification of the 13-HPL from guava fruit. (i) Preparation of the crude extract. Guava fruits were peeled and the pericarp tissues chopped into small pieces. Two volumes of extraction buffer $(50 \mathrm{mM}$ sodium phosphate, $0.1 \%$ Triton $\mathrm{X}-100 \mathrm{R}, 5 \mathrm{mM}$ sodium ascorbate, $\mathrm{pH}$ 7.0) were added to
$500 \mathrm{~g}$ of chopped pericarp and homogenized for $2 \mathrm{~min}$ in a Sorvall mixer at $4^{\circ} \mathrm{C}$. All of the following steps were carried out at room temperature.

(ii) Enzyme solubilization. The crude extract containing the 13-HPL activity was solubilized with $1 \%$ (vol/vol) of Triton $\mathrm{X}-100 \mathrm{R}$ with stirring for $30 \mathrm{~min}$. After centrifugation at $16,000 \times g$ for $15 \mathrm{~min}, 0.02 \%$ Pectinex Ultra SP-L solution from Novo Nordisk Ferment (Bagsvaerd, Denmark) was added to degrade pectin.

(iii) Ammonium sulfate precipitation. Solid $\left(\mathrm{NH}_{4}\right)_{2} \mathrm{SO}_{4}$ was added in small portions to the crude extract under stirring until $30 \%$ saturation was achieved. After stirring for 30 $\mathrm{min}$, the mixture was centrifuged at $20,000 \times g$ for $15 \mathrm{~min}$ and the resulting pellet discarded. The supernatant was brought to $60 \%$ saturation with more solid $\left(\mathrm{NH}_{4}\right)_{2} \mathrm{SO}_{4}$ added in portions. After stirring for $30 \mathrm{~min}$, the pellet was collected by centrifugation as above.

(iv) Gel permeation chromatography (GPC). The $\left(\mathrm{NH}_{4}\right)_{2} \mathrm{SO}_{4}$ pellet was dissolved in $45 \mathrm{~mL}$ of extraction buffer and chromatographed on a Superdex 200 HL 26/60 column (Pharmacia, Uppsala, Sweden) with $50 \mathrm{mM}$ sodium phosphate, $0.1 \%$ Triton X-100R pH 7.0 as running buffer at a flow rate of $2 \mathrm{~mL} / \mathrm{min}$. After GPC, samples were run on anion exchange chromatography or hydrophobic interaction chromatography (HIC) columns.

(v) Anion exchange chromatography. The sample from GPC was applied to a Q-Sepharose column (Pharmacia) with a loading buffer of $20 \mathrm{mM}$ Tris- $\mathrm{HCl} \mathrm{pH} 8.5$ containing $0.1 \%$ Triton X-100R. 13-HPL activity was eluted with a gradient of $\mathrm{NaCl}$ in eluting buffer $(0-100 \% 1 \mathrm{M} \mathrm{NaCl}$ in $133 \mathrm{~min}$ at a flow rate of $3 \mathrm{~mL} / \mathrm{min}$ ).

(vi) HIC. The fractions containing the 13-HPL activity from the GPC were brought to $30 \%\left(\mathrm{NH}_{4}\right)_{2} \mathrm{SO}_{4}$ saturation before loading onto a Phenyl-Sepharose HR 26/10 column (Pharmacia) with loading buffer $[50 \mathrm{mM}$ sodium phosphate, $1 \mathrm{M}\left(\mathrm{NH}_{4}\right)_{2} \mathrm{SO}_{4}, \mathrm{pH}$ 7.0]. The proteins were eluted with a decreasing salt gradient (100-0\% $1 \mathrm{M}$ ammonium sulfate over $70 \mathrm{~min}$ ) in $50 \mathrm{mM}$ sodium phosphate $\mathrm{pH} 7.0$ containing $1 \%$ Triton $\mathrm{X}-100 \mathrm{R}$ at a flow rate of $8 \mathrm{~mL} / \mathrm{min}$. Fractions containing the 13-HPL activity were concentrated by dialysis against polyethylene glycol 20,000 and desalted on a PD-10 column (Pharmacia) against the loading buffer for hydroxylapatite chromatography $(10 \mathrm{mM}$ sodium phosphate, $0.1 \%$ Triton $\mathrm{X}$ 100R, pH 6.8).

(vii) Hydroxylapatite chromatography. After HIC, the sample was applied to an Econo-Pac HTP column (BioRad, Cambridge, MA) in $10 \mathrm{mM}$ sodium phosphate, $0.1 \%$ Triton $\mathrm{X}-100 \mathrm{R}, \mathrm{pH}$ 6.8. The proteins were eluted with a gradient to $200 \mathrm{mM}$ sodium phosphate buffer $\mathrm{pH} 6.8$, containing $0.1 \%$ Triton X-100R over $30 \mathrm{~min}$ using a flow rate of $1 \mathrm{~mL} / \mathrm{min}$. Fractions with 13-HPL activity were concentrated by dialysis against polyethylene glycol 20,000 and desalted against the isoelectric focusing chromatography (IFC) loading buffer (75 mM Tris-acetic acid, $\mathrm{pH}$ 9.3).

(viii) IFC. The prepared sample from hydroxylapatite chromatography was applied to a Mono P HR 5/20 column (Phar- 
macia). The proteins were eluted with $10 \%$ Polybuffer 96 (Pharmacia)/acetic acid, pH 6.0, at a flow rate of $0.5 \mathrm{~mL} / \mathrm{min}$.

Tryptic digest and amino acid sequence determination. Fractions of purified 13-HPL were concentrated and separated on a $6.5 \%$ sodium dodecyl sulfate-polyacrylamide gel (SDS-PAGE). The proteins were electrotransferred $(0.8 \mathrm{~mA}$ $\mathrm{cm}^{-2}$ for $75 \mathrm{~min}$ ) to an Immobilon CD membrane (Millipore, Bedford, MA) using $10 \mathrm{mM}$ 3-[cyclohexylamino]-1-propanesulfonic acid containing 10\% (vol/vol) methanol pH 11.0 as transfer buffer. Proteins were detected by staining using Quick-Stain (Zoion Research Inc., Newton, MA).

Direct sequencing of the purified 13-HPL by Edman degradation was not possible as the N-terminus was blocked. The 13-HPL purified protein was therefore cut out separately and incubated in $10 \mu \mathrm{L}$ of $0.1 \mathrm{M}$ Tris pH 8.2 containing $1 \mathrm{M}$ $\mathrm{NaCl}, 10 \%$ (vol/vol) acetonitrile, $2 \mathrm{mM} \mathrm{CaCl}_{2}$, and $0.1 \mu \mathrm{g}$ trypsin at $37^{\circ} \mathrm{C}$ for $15 \mathrm{~h}$. After acidification with $1 \mu \mathrm{L}$ of $10 \%$ trifluoroacetic acid (TFA), the solution was injected directly into the high-pressure liquid chromatography (HPLC) system equipped with a Brownlee Aquapore RP-300 C8 column (PE Applied Biosystems, Foster City, CA). Chromatography solvents were $0.05 \%$ TFA and $2 \%$ acetonitrile in water (solvent A) and $0.045 \%$ TFA and $80 \%$ acetonitrile in water (solvent B). The gradient and flow rates used were as follows: 0-5 min, 80 $\mu \mathrm{L} / \mathrm{min}$ at $2 \%$ solvent $\mathrm{B} ; 5-65 \mathrm{~min} 50 \mu \mathrm{L} / \mathrm{min}$ at $2-65 \%$ solvent B; and $65-70 \mathrm{~min} 50 \mu \mathrm{L} / \mathrm{min}$ at $65-100 \% \mathrm{~B}$. Absorbance at $214 \mathrm{~nm}$ was measured in a $200 \mathrm{~nL}$ flow cell with a path length of $2 \mathrm{~mm}$. Peptides resolved by HPLC were collected manually for sequence analysis and applied to precycled polyprene-treated glass fiber discs. Automated sequencing used a model 477A pulsed-liquid phase sequencer (Applied Biosystems) equipped with a model 120A analyzer.

$R N A$ isolation. Total RNA was extracted using the method of Wan and Wilkins (16). Immature guava fruit (1 g) was crushed to a fine powder in liquid nitrogen in a precooled pestle and mortar. The powder was added to $5 \mathrm{~mL}$ at $80^{\circ} \mathrm{C}$ of lysis buffer [200 mM borax, $30 \mathrm{mM}$ EGTA, $10 \mathrm{mM}$ dithiothreitol, $1 \% \mathrm{wt} / \mathrm{vol}$ SDS, $1 \% \mathrm{wt} / \mathrm{vol}$ sodium deoxycholate, $2 \%$ PVP 40,000 (Sigma Chemical Co., St. Louis, MO), 0.5\% vol/vol NP-40 (Sigma)] and the mixture homogenized. Proteinase K (2.5 mg, Sigma) was added, and this mixture was incubated at $42^{\circ} \mathrm{C}$ for 90 min with shaking sufficient for mixing without excessive foaming. One milliliter of $1 \mathrm{M} \mathrm{KCl}$ was added. After mixing, the tubes were incubated on ice for $1 \mathrm{~h}$ and then centrifuged at $10,000 \times g$ for $10 \mathrm{~min}$. Three milliliters of $4 \mathrm{M} \mathrm{LiCl}$ was added, and the tubes were incubated at $4^{\circ} \mathrm{C}$ overnight. After $10 \mathrm{~min}$ of centrifugation at $10,000 \times \mathrm{g}$, the supernatant was discarded, and the pellet washed with 2 $\mathrm{M} \mathrm{LiCl}$ and centrifuged as before. The supernatant was discarded and the pellet resuspended in Tris/EDTA buffer (10 mM Tris, $\mathrm{pH} 8,1 \mathrm{mM}$ EDTA) or in $\mathrm{H}_{2} \mathrm{O}$.

For the purification of mRNA from total RNA, the mRNA purification kit from Pharmacia was used. This kit is based on the use of spun columns for the affinity purification of polyadenylated RNA on oligo(dT)-cellulose. The RNA was quantified by ultraviolet (UV) spectrophotometry. The yield was approximately $1 \mathrm{mg}$ of total RNA and $20 \mu \mathrm{g}$ of mRNA.

Cloning. (i) cDNA synthesis. Total RNA $(20 \mu \mathrm{g})$ or $1 \mu \mathrm{g}$ of mRNA was used in $50-\mu \mathrm{L}$ reactions for the first strand cDNA synthesis using an oligo(dT)-adaptor primer (17). Aliquots of $1 \mu \mathrm{L}$ cDNA were used directly in polymerase chain reactions (PCR).

(ii) PCR cloning. The PCR were primed with $1 \mu \mathrm{L}$ cDNA (from a $50-\mu \mathrm{L}$ cDNA synthesis using $20 \mu \mathrm{g}$ total RNA), and using $10 \mathrm{mM}$ Tris, $\mathrm{pH} 8.3,50 \mathrm{mM} \mathrm{KCl,} 3 \mathrm{mM} \mathrm{MgCl}_{2}$ with $0.2 \mathrm{mM}$ each of dNTPs and $0.25 \mu \mathrm{L}$ (1.25 units) of AmpliTaq DNA polymerase (PerkinElmer) in a PerkinElmer 480 thermocycler. After the addition of the cDNA at $80^{\circ} \mathrm{C}$ (hot start), the PCR reactions conditions were: $94^{\circ} \mathrm{C}, 2 \mathrm{~min}$ for 1 cycle; $50-55^{\circ} \mathrm{C}$ for $1 \mathrm{~min}, 72^{\circ} \mathrm{C}$ for $1 \mathrm{~min}$, and $94^{\circ} \mathrm{C}$ for $1 \mathrm{~min}$ for 30 cycles; $72^{\circ} \mathrm{C}$ for $10 \mathrm{~min}$ for 1 cycle; and the block temperature was held at $4^{\circ} \mathrm{C}$.

$3^{\prime}$-Rapid amplification of cDNA ends (RACE) and 5'RACE: The 3'-sequence was obtained using gene-specific upstream primers: ${ }^{5^{\prime}} \mathrm{CCT}$ CAA CAC GCT CAG GTG AAG ${ }^{3^{\prime}}$, ${ }^{5} \mathrm{CTC}$ CAA AAG TTC CTC TTC AAC $\mathrm{TTC}^{3^{\prime}}$, or ${ }^{5^{\prime}} \mathrm{CCA}$ GCT CCT CCC CAC CAT CAA ${ }^{3^{\prime}}$ against a downstream primer based on the adaptor-linked oligo(dT) primer used for cDNA synthesis (17). The 5'RACE was accomplished using a kit from GibcoBRL (Grand Island, NY), according to the manufacturer's instructions. The gene-specific downstream primers were: ${ }^{5}$ GTC AGC GCC GAA GAT GGA CTT ${ }^{3^{\prime}}$ or ${ }^{5}$ GTG TTG AGG CTC GGA AGT GTC ${ }^{3}$.

Full-length clones obtained by PCR. Four gene-specific primers were synthesized corresponding to the putative start sites of the coding sequence (at the four different methionines) and one primer corresponding to the stop codon. $B a m \mathrm{HI}$ and EcoRI restrictions sites were incorporated at the $5^{\prime}$ and $3^{\prime}$ ends, respectively, to facilitate subcloning. The four upstream primers were: ${ }^{\prime}$ TAG GAT CCG ATC ATG GCG AGG GTC GTG ${ }^{3}$, ${ }^{5}$ GCG GAT CCG GCC ATG AGC AAC ATG TCG $^{3^{\prime}},{ }^{\prime}$ GCG GAT CCG GCC ATG TCG CCG GCC $\mathrm{AT}^{3^{\prime}}$, and ${ }^{5^{\prime}} \mathrm{GCG}$ GAT CCG GCC ATG TCG TCC ACC $\mathrm{TAC}^{3^{\prime}}$; and the downstream primer was: ${ }^{5^{\prime}} \mathrm{GCG}$ AAT TCT CAG TTG GCC TTT TCA ACG GCT GT ${ }^{3^{\prime}}$. These primers were purified by HPLC as the dimethoxytrityl derivative (17). After deprotection, they were used in PCR reactions (at 20 $\mathrm{pmol} / 50 \mu \mathrm{L}$ final concentration) with a proof-reading mixture of Taq/Pwo DNA polymerase (Expand High Fidelity, Boehringer-Mannheim, Indianapolis, IN) according to the manufacturer's instructions. The reactions conditions were $94^{\circ} \mathrm{C}, 2 \mathrm{~min}$ for $1 \mathrm{cycle} ; 60^{\circ} \mathrm{C}$ for $1 \mathrm{~min}, 72^{\circ} \mathrm{C}$ for $1 \mathrm{~min}$, and $94^{\circ} \mathrm{C}$ for $1 \mathrm{~min}$ for $30 \mathrm{cycles} ; 72^{\circ} \mathrm{C}$ for $10 \mathrm{~min}$ for $1 \mathrm{cycle}$; and the block temperature was held at $4^{\circ} \mathrm{C}$.

DNA sequencing. cDNA were sequenced using the Thermo Sequenase radiolabeled terminator cycle sequencing kit (Amersham Life Science, Inc., Arlington Heights, IL).

Bacterial expression. (i) Preparation of constructs. The four cDNAs encoding the 13-HPL-Met 1, 6, 9, and 13 in pCR2.1 were cut with BamHI and EcoRI and subcloned into the expression vector plasmid pET30b (Novagen) digested 
also with BamHI and EcoRI. The 13-HPL-Met 1, 6, 9, and 13 constructs were transformed into $E$. coli strain XLI-Blue. The plasmid DNA was then used for transformation of $E$. coli strain BL21(DE3) to express the 13-HPL.

(ii) Preparation of bacterial cultures. The four different constructs described above were expressed in BL21(DE3) (Novagen, Madison, WI) cells using a modified expression methodology (18). A typical preparation of 50-mL culture was carried out as follows: A single bacterial colony from a complex agar plate containing $30 \mu \mathrm{g} / \mathrm{mL}$ of kanamycin was grown in $1 \mathrm{~mL}$ of $\mathrm{LB}$ medium containing $50 \mu \mathrm{g} / \mathrm{mL}$ of kanamycin at $37^{\circ} \mathrm{C}$ and $250 \mathrm{rpm}$ for $3 \mathrm{~h}$. An aliquot $(200 \mu \mathrm{L})$ of this culture was used to inoculate $10 \mathrm{~mL}$ of TB medium containing $50 \mu \mathrm{g} / \mathrm{mL}$ of kanamycin and the culture was again grown at $37^{\circ} \mathrm{C}$. After $3 \mathrm{~h}$, this culture was diluted with $40 \mathrm{~mL}$ of TB containing $30 \mu \mathrm{g} / \mathrm{mL}$ of kanamycin and grown at $28^{\circ} \mathrm{C}$, $250 \mathrm{rpm}$ for $24 \mathrm{~h}$. The bacterial cells were centrifuged at $4^{\circ} \mathrm{C}$ for $15 \mathrm{~min}$ at $5,000 \mathrm{rpm}(3,500 \times \mathrm{g})$ in a Jouan CR422 centrifuge, washed by resuspension in $10 \mathrm{~mL}$ of Tris- $\mathrm{HCl}$ buffer $50 \mathrm{mM} \mathrm{pH} \mathrm{7.9,} \mathrm{and} \mathrm{centrifuged} \mathrm{as} \mathrm{before.} \mathrm{The} \mathrm{resulting} \mathrm{pel-}$ let of cells was resuspended in $10 \mathrm{~mL}$ of Tris-acetate buffer $100 \mathrm{mM}$ pH 7.6 containing $500 \mathrm{mM}$ of sucrose, $0.5 \mathrm{mM}$ of EDTA, and $1 \mathrm{mg} / \mathrm{mL}$ of lysozyme. After $30 \mathrm{~min}$ on ice, the cells were centrifuged as before to obtain a pellet of spheroplasts which were resuspended in $10 \mathrm{~mL}$ of potassium phosphate buffer (100 mM, pH 7.6). After at least $10 \mathrm{~min}$ at $-80^{\circ} \mathrm{C}$, a protease inhibitor (phenylmethylsulfonyl fluoride, 1 $\mathrm{mM}$ ) was added, the cells were allowed to thaw for $10 \mathrm{~min}$, and then they were sonicated twice for $30 \mathrm{~s}$ using a Virsonic 100 at a setting of 5 . The resulting membranes were spun down at $100,000 \times g$ for $90 \mathrm{~min}$ at $4^{\circ} \mathrm{C}$. The 13 -HPL activity was recovered in the $100,000 \times g$ pellet. After solubilization using 1\% Emulphogen BC-700 ${ }^{\mathrm{TM}}$ (polyoxyethylene 10 tridecyl ether, Sigma) at $4^{\circ} \mathrm{C}$ overnight and centrifugation as before, the 13-HPL activity was recovered in the supernatant.

Purification of His-tagged proteins. The histidine-tagged 13-HPL was purified following the protocol described by Imai et al. (19). After solubilization, the $100,000 \times g$ supernatant was loaded on a Ni-nitrilotriacetic acid (NTA) column ( $0.5 \mathrm{~mL}$ bed volume, Qiagen, Valencia, CA) equilibrated with potassium phosphate buffer $50 \mathrm{mM}$ pH 7.6 containing 100 $\mathrm{mM} \mathrm{NaCl}$ and $0.1 \%$ Emulphogene BC-720 detergent (buffer A) at $0.5 \mathrm{~mL} / \mathrm{min}$. The column was washed with the buffer $\mathrm{A}$ containing $50 \mathrm{mM}$ glycine. The His-13-HPL was then eluted with the buffer A containing $40 \mathrm{mM}$ L-histidine. Fractions of $1 \mathrm{~mL}$ were collected and assayed for the 13-HPL activity. Fractions containing the 13-HPL activity were dialyzed overnight against potassium phosphate $100 \mathrm{mM}, \mathrm{pH} 7.6 \mathrm{using}$ a microdialyzer (Pierce, Rockford, IL).

Enzyme assays. (i) UV assay. 13-Hydroperoxides from linolenic and linoleic acids were produced with soybean lipoxygenase L1 (type V, Sigma) according to the methods of Vick (20) or Brash and Song (21). 13-HPL activity was measured by following the decrease in absorbance at $234 \mathrm{~nm}$, representing disruption of the conjugated diene system in the fatty acid hydroperoxide substrate. The assay contained 5-10 $\mu \mathrm{g}$ of fatty acid 13-hydroperoxide in $0.5 \mathrm{~mL}$ of $100 \mathrm{mM}$ potassium phosphate buffer at $\mathrm{pH} 7$.

For the HPLC assay, 50 or $100 \mu \mathrm{M}$ of a mixture of unlabeled and $\left[1-{ }^{14} \mathrm{C}\right]-13(S)$-hydroperoxylinole(n)ic acid $(200,000 \mathrm{cpm})$ was used in $100 \mathrm{mM}$ potassium phosphate buffer at $\mathrm{pH}$ 7. The reactions were stopped with $100 \mu \mathrm{L}$ potassium dihydrogen phosphate $(1 \mathrm{M})$ and the products extracted twice with $0.5 \mathrm{~mL}$ ethyl acetate. The combined organic phases were washed with water and dried under a stream of nitrogen. The extracts were dissolved in $50 \mu \mathrm{L}$ methanol and stored at $-20^{\circ} \mathrm{C}$ under argon prior to analysis. The compounds were analyzed using a Beckman Ultrasphere ODS column $(5 \mu \mathrm{m}, 25 \times 0.46 \mathrm{~cm})$ using $\mathrm{MeOH} / \mathrm{H}_{2} \mathrm{O} /$ glacial acetic acid (77.5:22.5:0.01, by vol) as solvent at a flow rate of $1.1 \mathrm{~mL} / \mathrm{min}$. Products were detected online using a Hewlett-Packard 1040A diode array detector and a Packard Flo-One radioactive monitor. The main ${ }^{14} \mathrm{C}$-labeled enzymatic product from $\left[1-{ }^{14} \mathrm{C}\right] 13(S)$-hydroperoxylinolenic acid on reversed-phase (RP)-HPLC (12-oxo-dodecenoic acid) was resolved into the main $9 Z$ isomer and the $10 E$ isomer formed during sample workup by normal-phase HPLC on a Beckman $5 \mu \mathrm{m}$ silica column $(25 \times 0.46 \mathrm{~cm})$ with a solvent of hexane/isopropanol/glacial acetic acid (100:1:0.01, by vol). The $9 \mathrm{Z}$ isomer chromatographed as a broad symmetrical peak (retention volume $17-22 \mathrm{~mL}$ ), and the $10 E$ isomer as a typically shaped peak at $24 \mathrm{~mL}$. The two compounds were converted to the methoxime derivative (which eliminated further isomerization of the $9 \mathrm{Z}$ double bond) and methyl ester derivative and analyzed by GC-mass spectrometry (MS).

$G C-M S$. GC-MS analyses were carried out in the electron impact mode $(70 \mathrm{eV})$ using a Finnigan Incos 50 mass spectrometer (for 3Z-hexenal analysis) or a Hewlett-Packard 5889A mass spectrometer (for 12-oxo-dodecenoate analysis), each coupled to a Hewlett-Packard 5890 gas chromatograph equipped with a SPB-1 fused-silica capillary column (15 or $30 \mathrm{~m} \times 0.25 \mathrm{~mm}$ internal diameter). Samples were injected at $60^{\circ} \mathrm{C}$, and the temperature was subsequently programmed to $300^{\circ} \mathrm{C}$ at 10 or $20^{\circ} / \mathrm{min}$.

\section{RESULTS}

13-HPL in fruits and vegetables. The fruits of a number of commonly available plants were screened for the ability to convert 13-hydroperoxylinoleic acid (Table 1) and 13-hydroperoxylinolenic acid (Table 1 ) to the corresponding $\mathrm{C}_{6} \mathrm{HPL}$ products. On the basis of these results, initially bean was selected as a readily available and relatively inexpensive material for the purification of the enzyme. However, in pilot experiments the bean lyase proved to be unstable to freeze-thawing, and this compromised our ability to purify the enzyme. Accordingly, guava was chosen as an even more promising candidate on the basis of activity. It was soon established that this enzyme survived freezing and that its robust properties permitted its purification through multiple chromatographic steps.

Purification of the guava 13-HPL. Preliminary work confirmed literature reports that $13-\mathrm{HPL}$ is a membrane-bound 
TABLE 1

Screening of Plants for 13-Hydroperoxide Lyase Activity

\begin{tabular}{lclc}
\hline Screening for 13-HPOD lyase activity & & \\
\hline Vegetable & Hexanal $^{a}$ & Fruit & Hexanal $^{a}$ \\
Alfalfa & 1.36 & Apple & 0.38 \\
Bean (green) & 0.82 & Banana & 0.31 \\
Bean (white) & 0.78 & Cashew fruit & $<0.1$ \\
Celery leaf & 0.16 & Grape & 0.33 \\
Fennel & 0.12 & Kiwi & 0.27 \\
Parsley & 0.20 & Orange & 0.61 \\
Pea & 0.25 & Papaya & 0.73 \\
Pepper (green) & 0.89 & Pear & 0.33 \\
Radish leaf & 0.23 & Pineapple & 0.19 \\
Soya (sprout) & 0.25 & Raspberry & 0.37 \\
Tomato & 0.51 & Strawberry & 0.40 \\
Turnip & 0.20 & Guava & 2.20 \\
\hline
\end{tabular}

\begin{tabular}{lclc}
\hline Screening for 13-HPOT lyase activity & & \\
\hline Vegetable & $(Z)-3+(E)-2-$ Hexenal $^{a}$ & Fruit & $(Z)-3+(E)-2-$ Hexenal $^{a}$ \\
Alfalfa & 0.21 & Apple & 0.22 \\
Celery & $<0.1$ & Banana & 0.13 \\
Cucumber & 0.28 & Apricot & 0.23 \\
Lettuce & $<0.1$ & Cherry & $<0.1$ \\
Pea & $<0.1$ & Kiwi & 0.24 \\
Pepper (green) & 0.37 & Orange & 0.23 \\
Radish leaf & 0.10 & Papaya & 0.11 \\
Soya (sprout) & $<0.1$ & Melon (water $)$ & $<0.1$ \\
Tomato & $<0.1$ & Raspberry & $<0.1$ \\
Sorrel & $<0.1$ & Strawberry & $<0.1$ \\
& & Guava & 1.18 \\
\hline
\end{tabular}

${ }^{a} \mathrm{~g} / \mathrm{kg}$ reaction.

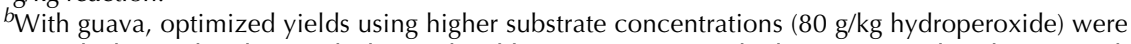
$5.07 \mathrm{~g} / \mathrm{kg}$ hexanal and $1.43 \mathrm{~g} / \mathrm{kg}$ hexenals. Abbreviations: HPOD, hydroperoxyoctadecadienoic acid; HPOT, hydroperoxyoctadecatrienoic acid.

enzyme and that detergents are necessary to solubilize the enzyme (11). The guava tissue was homogenized with a sodium phosphate buffer pH 7.0 containing $5 \mathrm{mM}$ sodium ascorbate to prevent oxidation and $0.1 \%$ Triton $\mathrm{X}-100 \mathrm{R}$. When the concentration of Triton X-100R was increased to $1 \%$ (vol/vol) and the homogenate was stirred for $30 \mathrm{~min}$, the yield of soluble and active 13-HPL was doubled (data not shown).

A typical purification of 13-HPL from guava fruit is shown in Table 2 . The crude extract was concentrated by $\left(\mathrm{NH}_{4}\right)_{2} \mathrm{SO}_{4}$ precipitation followed by a subsequent GPC step on a Superdex 200 column (Pharmacia). The fractions containing 13-HPL ac- tivity were pooled and chromatographed on an HIC column. After concentration and desalting, the pooled active fractions were chromatographed on a hydroxylapatite column. The eluted 13-HPL activity was again concentrated, desalted, and loaded onto an IFC column. Each purification step resulted in a considerable loss of 13-HPL activity, which was probably not due to proteolysis, and only $0.2 \%$ of the initial $13-\mathrm{HPL}$ activity was recovered (Table 2). Analysis of the preparation by SDSPAGE showed that the purified sample contained only one, apparently homogenous band with an apparent molecular weight of $48 \mathrm{kD}$. Because of the high losses of 13-HPL activity, an

TABLE 2

Purification of 13-Hydroperoxide Lyase from Guava Fruit $^{a}$

\begin{tabular}{lrrrrr}
\hline Purification & $\begin{array}{c}\text { Total } \\
\text { protein } \\
\text { step }\end{array}$ & $\begin{array}{c}\text { Total } \\
\text { 13-HPL } \\
\text { activity } \\
\text { (nkat) }\end{array}$ & $\begin{array}{c}\text { Recovered } \\
\text { activity } \\
(\%)\end{array}$ & $\begin{array}{c}\text { Specific } \\
13-\mathrm{HPL} \\
\text { activity } \\
\left(\text { nkat } \mathrm{mg}^{-1}\right)\end{array}$ & $\begin{array}{c}\text { Purification } \\
\text { factor }\end{array}$ \\
\hline Crude extract & 1,111 & 172,050 & 100.0 & 155 & - \\
$30-60 \%\left(\mathrm{NH}_{4}\right)_{2} \mathrm{SO}_{4}$ pellet & 762 & 62,300 & 36.2 & 82 & - \\
GPC & 39 & 32,640 & 19.0 & 837 & 5.4 \\
HIC & 16 & 15,160 & 8.8 & 947 & 6.1 \\
Hydroxylapatite & 1.6 & 6,500 & 3.8 & 4,062 & 26.2 \\
IFC & 0.03 & 317 & 0.2 & 10,566 & 68.2 \\
\hline
\end{tabular}

${ }^{a} \mathrm{HPL}$, hydroperoxide lyase; GPC, gel permeation chromatography; HIC, hydrophobic interaction chromatography; IFC, isoelectric focusing chromatography. 

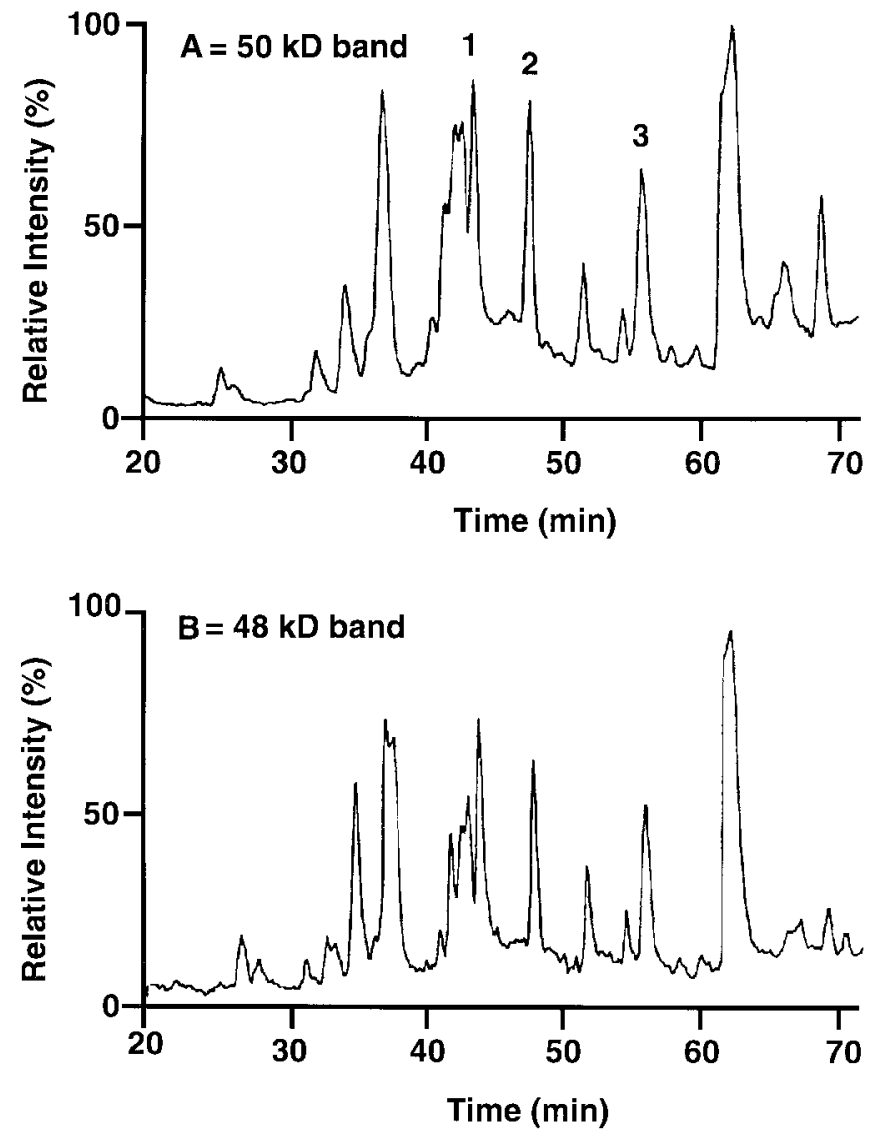

FIG. 1. High-pressure liquid chromatography (HPLC) analysis of purified guava 13-hydroperoxide lyase (13-HPL) digested with trypsin: comparison of the peptide maps of the 50 and $48 \mathrm{kD}$ protein bands.

anion exchange chromatography step was used in place of HIC. In this case, analysis of the purified enzyme by SDS-PAGE showed two bands of 48 and $50 \mathrm{kD}$. The 13-HPL purified from guava fruit tissue had maximal activity around $\mathrm{pH} 6.0$ and a pI of 6.8 determined by chromatofocusing.

The HPLC peptide maps of the trypsin cleavage products from the two protein bands are very similar (Fig. 1), indicating that there are only minor differences in amino acid composition and/or posttranslational modification. Three peptides of the $50 \mathrm{kD}$ band were sequenced (Table 3).

A computer-aided search of the Swissprot and genEMBL databases found that five amino acids of peptide 3 (Phe Asn Phe Leu Ser, Table 3) are identical to amino acids 236 to 240

TABLE 3

Peptide Sequences Obtained from HPLC-Purified Tryptic Fragments

\begin{tabular}{cl}
\hline Peptide $^{a}$ & \multicolumn{1}{c}{ Sequence $^{b}$} \\
\hline 1 & Asp Gly Asn Ala Ser Val Ile Phe Pro Leu Gln (Lys) \\
2 & Asn Phe Ala Met Asp Ile Leu (Lys) \\
3 & Phe Leu Phe Asn Phe Leu Ser (Lys) \\
\hline
\end{tabular}

${ }^{a}$ These numbers correspond to the peak number obtained during purification by high-performance liquid chromatography (HPLC).

${ }^{b}$ As trypsin cleaves specifically on the carbonyl side of lys-arg linkages, the residues in parentheses are predicted. of flaxseed allene oxide synthase (AOS) (22). At this stage there was no obvious homology between the peptide sequences and the 13-HPL from green bell pepper fruit (14).

Cloning. Sense and antisense degenerate oligonucleotides (Table 4) deduced from the peptides sequences (Table 3) were synthesized. PCR reactions were performed using the different pairs of oligonucleotides with or without cDNA as template. One main product of $160 \mathrm{bp}$ was subcloned and sequenced, and this was found to contain the three peptides, which were thus from the same peptide chain (see later). Moreover, a multiple alignment of this sequence with the AOS from flax (22), the AOS from guayule (23), the 13-HPL from green pepper (14), and the 13-HPL from Arabidopsis (15) showed the highest homology with the 13-HPL enzymes.

The remainder of the cDNA from guava fruit was cloned using 3'- and 5'-RACE (see Experimental Procedures section). cDNA corresponding to the open reading frame was prepared by PCR using a proof-reading mixture of Taq/Pwo as DNA polymerase. An amplification product was obtained, subcloned, and sequenced. The complete cDNA (1467 bp) and deduced amino acid sequence are shown in Figure 2. The open reading frame encodes a total of 489 amino acids corresponding to a protein with a molecular weight of 54,817 Daltons. The isoelectric point of the protein is estimated to be 7.29. Previously, the molecular weight of the native protein was estimated by SDS-PAGE as $50 \mathrm{kD}$, and we found a $\mathrm{pI}$ of 6.8 using chromatofocusing. The derived amino acid sequence has an identity of $65 \%$ with the pepper 13-HPL (14). The guava cDNA encodes four possible start sites within the first 13 amino acids (methionines 1, 6, 9, and 13) whereas the pepper gene has only two methionines, corresponding to guava-Met9 and guava-Met13.

Expression. Four different cDNA clones of the 13-HPL (13-HPL-Met1, -Met6, -Met9, -Met13) were inserted into the E. coli expression plasmids pET30b (see Experimental Procedures section) and transformed into E. coli strain BL21(DE3). The expression level was examined at different induction temperatures, with or without addition of isopropyl$\beta$-D-thiogalactopyranoside (IPTG) and the heme precursor, $\delta$-aminolevulinic acid ( $\delta$-ALA). The best activities were obtained at $28^{\circ} \mathrm{C}$ with both $\delta$-ALA and IPTG omitted. Thus, in the system used here, with the pET30 plasmid, its T7 RNA

TABLE 4

Oligonucleotides Designed from Peptide Sequence for PCR Cloning Experiments

\begin{tabular}{cl}
\hline Oligonucleotide name & \multicolumn{1}{c}{ Sequence $^{a}\left(5^{\prime}\right.$ - $^{\prime}$ ' orientation $)$} \\
\hline $12 \mathrm{Sa}$ & GAYGGNAAYGCNTCNGTNATHTTYCCNYT \\
$12 \mathrm{Sb}$ & GAYGGNAAYGCNAGYGTNATHTTYCCNYT \\
$12 \mathrm{Aa}$ & CTRCCNTTRCGNAGNCANTADAARGGNRA \\
$12 \mathrm{Ab}$ & CTRCCNTTRCGNTCRCANTADAARGGNRA \\
$13 \mathrm{~S}$ & AAYTTYGCNATGGAYATHYT \\
$13 \mathrm{~A}$ & TTRAARCGNTACCTRTADRA \\
$15 \mathrm{~S}$ & TTYCTNTTYAAYTTYYT \\
$15 \mathrm{~A}$ & AARGANAARTTRAARRA \\
\hline
\end{tabular}

${ }^{a}$ Codes used here for the mixed bases are: $D=G, A, T ; H=A, T, C ; R=A$, $\mathrm{G} ; \mathrm{Y}=\mathrm{C}, \mathrm{T}$. PCR, polymerase chain reaction. 
ATG GCG AGG GTC GTG ATG AGC AAC ATG TCG CCG GCC ATG TCG TCC ACC TAC CCC CCG TCT CTG TCC $\begin{array}{lllllllllllllllllllllllll}\mathbf{M} & \mathrm{A} & \mathrm{R} & \mathrm{V} & \mathrm{V} & \mathbf{M} & \mathrm{S} & \mathrm{N} & \mathbf{M} & \mathrm{S} & \mathrm{P} & \mathrm{A} & \mathbf{M} & \mathrm{S} & \mathrm{S} & \mathrm{T} & \mathrm{Y} & \mathrm{P} & \mathrm{P} & \mathrm{S} & \mathrm{L} & \mathrm{S}\end{array}$ CCG CCG TCG TCG CCG CGG CCG ACC ACC CTC CCG GTG CGG ACG ATC CCG GGC AGC TAC GGG TGG CCC $\begin{array}{lllllllllllllllllllllll}P & P & S & S & P & R & P & T & T & L & P & V & R & T & I & P & G & S & Y & G & W & P\end{array}$ CTC CTC GGC CCG ATA TCG GAC CGC CTG GAC TAC TTC TGG TTC CAA GGC CCG GAG ACG TTC TTC AGG $\begin{array}{lllllllllllllllllllllll}L & L & G & P & I & S & D & R & L & D & Y & F & W & F & Q & G & P & E & T & F & F & R\end{array}$ AAG AGG ATC GAG AAG TAC AAG AGC ACC GTG TTC CGC GCG AAC GTG CCT CCG TGC TTC CCC TTC TTC $\begin{array}{lllllllllllllllllllllll}K & R & I & E & K & Y & K & S & T & V & F & R & A & N & V & P & P & C & F & P & F & F\end{array}$ TCG AAC GTG AAC CCT AAC GTC GTG GTC GTC CTC GAT TGC GAG TCC TTC GCT CAC TTG TTC GAC ATG $\begin{array}{llllllllllllllllllllll}S & N & V & N & P & N & V & V & V & V & L & D & C & E & S & F & A & H & L & F & D & M\end{array}$ GAG ATC GTG GAG AAG AGC AAC GTC CTC GTC GGC GAC TTC ATG CCG AGC GTG AAG TAC ACC GGG AAC $\begin{array}{llllllllllllllllllllllllll}E & I & V & E & K & S & N & V & L & V & G & D & F & M & P & S & V & K & Y & T & G & N\end{array}$ ATC CGG GTC TGC GCT TAC CTC GAC ACT TCC GAG CCT CAA CAC GCT CAG GTG AAG AAC TTT GCG ATG $\begin{array}{llllllllllllllllllllll}I & R & V & C & A & Y & L & D & T & S & E & P & Q & H & A & Q & V & K & \mathbf{N} & \mathbf{F} & \mathbf{A} & \mathbf{M}\end{array}$ GAC AtA CTG AAg AGg AGC TCC AAA GTG TGG GAg AGC GAA GTG ATC TCG AAC TTG GAC ACC ATG TGG $\begin{array}{llllllllllllllllllllll}D & I & I & K & R & S & S & K & V & W & E & S & E & V & I & S & N & I & D & T & M & W\end{array}$ GAC ACC ATC GAG TCC AGC CTC GCC AAG GAC GGC AAC GCC AGC GTC ATC TTC CCT CTC CAA AAG TTC $\begin{array}{llllllllllllllllllllll}\mathrm{D} & \mathrm{T} & \mathrm{I} & \mathrm{E} & \mathrm{S} & \mathrm{S} & \mathrm{L} & \mathrm{A} & \mathrm{K} & \mathbf{D} & \mathbf{G} & \mathbf{N} & \mathbf{A} & \mathbf{S} & \mathbf{V} & \mathbf{I} & \boldsymbol{F} & \mathbf{P} & \mathbf{L} & \boldsymbol{Q} & \mathrm{K} & \mathbf{F}\end{array}$ CTC TTC AAC TTC CTC TCC AAG TCC ATC ATC GGC GCT GAC CCG GCC GCC TCG CCG CAG GTG GCC AAG $\begin{array}{llllllllllllllllllllllllll}\text { L } & \mathbf{F} & \mathbf{N} & \mathbf{F} & \mathrm{I} & \mathbf{S} & \mathrm{K} & \mathrm{S} & \mathrm{I} & \mathrm{I} & \mathrm{G} & \mathrm{A} & \mathrm{D} & \mathrm{P} & \mathrm{A} & \mathrm{A} & \mathrm{S} & \mathrm{P} & \mathrm{Q} & \mathrm{V} & \mathrm{A} & \mathrm{K}\end{array}$ TCC GGC TAC GCC ATG CTT GAC CGG TGG CTC GCT CTC CAG CTC CTC CCC ACC ATC AAC ATT GGC GTA

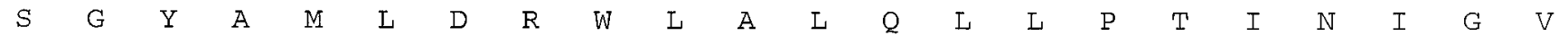
CTG CAG CCT CTA GTG GAG ATT TTT CTG CAT TCT TGG GCA TAC CCT TTT GCG CTG GTG AGC GGG GAC $\begin{array}{llllllllllllllllllllllll}L & Q & P & L & V & E & I & F & L & H & S & W & A & Y & P & F & A & L & V & S & G & D\end{array}$ TAC AAC AAG CTC TAC CAG TTC ATC GAG AAG GAA GGC CGA GAA GCG GTC GAA AGG GCG AAG GCC GAG $\begin{array}{llllllllllllllllllllll}Y & N & K & L & Y & Q & F & I & E & K & E & G & R & E & A & V & E & R & A & K & A & E\end{array}$ TTC GGA TTG ACA CAC CAG GAG GCC ATC CAC AAC TTG CTG TTC ATC CTC GGC TTC AAC GCG TTC GGC $\begin{array}{llllllllllllllllllllllllll} & \mathrm{G} & \mathrm{G} & \mathrm{L} & \mathrm{T} & \mathrm{H} & \mathrm{Q} & \mathrm{E} & \mathrm{A} & \mathrm{I} & \mathrm{H} & \mathrm{N} & \mathrm{L} & \mathrm{L} & \mathrm{F} & \mathrm{I} & \mathrm{L} & \mathrm{G} & \mathrm{F} & \mathrm{N} & \mathrm{A} & \mathrm{F} & G\end{array}$ GGC TTC TCG ATC TTC CTC CCC ACG TTG CTG AGC AAC ATA CTT AGC GAC ACA ACC GGA CTG CAG GAC

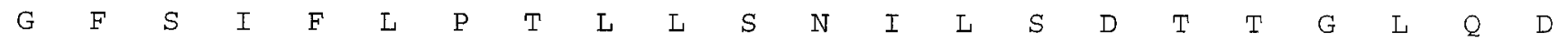
CGG CTG AGG AAG GAG GTC CGG GCA AAG GGA GGG CCG GCG TTG AGC TTC GCC TCG GTG AAG GAG ATG $\begin{array}{llllllllllllllllllllll}R & L & R & K & E & V & R & A & K & G & G & P & A & L & S & F & A & S & V & K & E & M\end{array}$ GAA CTC GTG AAG TCG GTC GTG TAC GAG ACG CTG CGG CTC AAC CCG CCC GTC CCG TTC CAA TAC GCT $\begin{array}{llllllllllllllllllllll}E & L & V & K & S & V & V & Y & E & T & L & R & L & N & P & P & V & P & F & Q & Y & A\end{array}$ CGA GCC CGG AAG GAC TTC CAG CTC AAG TCC CAC GAC TCT GTC TTT GAT GTC AAG AAA GGC GAG CTG $\begin{array}{llllllllllllllllllllll}R & A & R & K & D & F & Q & L & K & S & H & D & S & V & F & D & V & K & K & G & E & I\end{array}$ CTA TGC GGG TAT CAG AAG GTG GTG ATG ACA GAC CCG AAA GTG TTC GAC GAA CCG GAG AGC TTC AAC $\begin{array}{llllllllllllllllllllll}\mathrm{L} & \mathrm{C} & \mathrm{G} & \mathrm{Y} & \mathrm{Q} & \mathrm{K} & \mathrm{V} & \mathrm{V} & \mathrm{M} & \mathrm{T} & \mathrm{D} & \mathrm{P} & \mathrm{K} & \mathrm{V} & \mathrm{F} & \mathrm{D} & \mathrm{E} & \mathrm{P} & \mathrm{E} & \mathrm{S} & \mathrm{F} & \mathrm{N}\end{array}$ TCG GAC CGG TTC GTC CAA AAC AGC GAG CTA CTG GAT TAC CTG TAC TGG TCC AAC GGG CCG CAG ACC $\begin{array}{llllllllllllllllllllllllll}S & D & R & F & V & Q & N & S & E & L & L & D & Y & L & Y & W & S & N & G & P & Q & T\end{array}$ GGA ACG CCG ACC GAG TCG AAC AAG CAG TGC GCG GCT AAG GAC TAC GTC ACC CTC ACC GCT TGT CTC $\begin{array}{llllllllllllllllllllll}G & T & P & T & E & S & N & K & Q & C & A & A & K & D & Y & V & T & L & T & A & C & L\end{array}$ TTC GTT GCC TAC ATG TTT CGA CGG TAC AAT TCC GTC ACA GGA AGC TCG AGC TCG ATC ACA GCC GTT $\begin{array}{llllllllllllllllllllllll}F & V & A & Y & M & F & R & R & Y & N & S & V & T & G & S & S & S & S & I & T & A & V\end{array}$ GAA AAG GCC AAC TGA GTT TGA CGC GTG TTT ATG TTG TAC GGG CCA TTT GGG CTT TGT TGG GCT TGA E $\quad$ K $A$ A

GGC CCA GCC CAT TAT CCA TAC AGT GCG ATG GCC TCT TCA TAA GCG GTT CTC AAT CTC AAg TCC ACA CCC TGA TGT ATG GTG GAG GCA ATA AGT CAT CCT TGA AAT GAT TTA AAG TAT GAA CAG CCG TTC AAT CCA AAA AAA AAA AAA

FIG. 2. Nucleotide and deduced amino acid sequence of the guava 13-HPL. The four N-terminal methionines are boxed. The location of three peptides of known amino acid sequence are shown in bold. The enzyme is classified as CYP74B5, and the GenBank accession number is AF239670. For abbreviation see Figure 1.

polymerase promoter, and with the cells grown in a rich medium (TB), addition of heme precursor or IPTG inducer did not help with expression of active lyase.

Proteins from the transformed and induced cells were ana- lyzed by SDS-PAGE (Fig. 3). High levels of protein with the expected molecular weight were expressed under all culture conditions (Fig. 3; lanes 2, 3, and 4). These levels appear to account for about half of the cellular protein. We obtained 


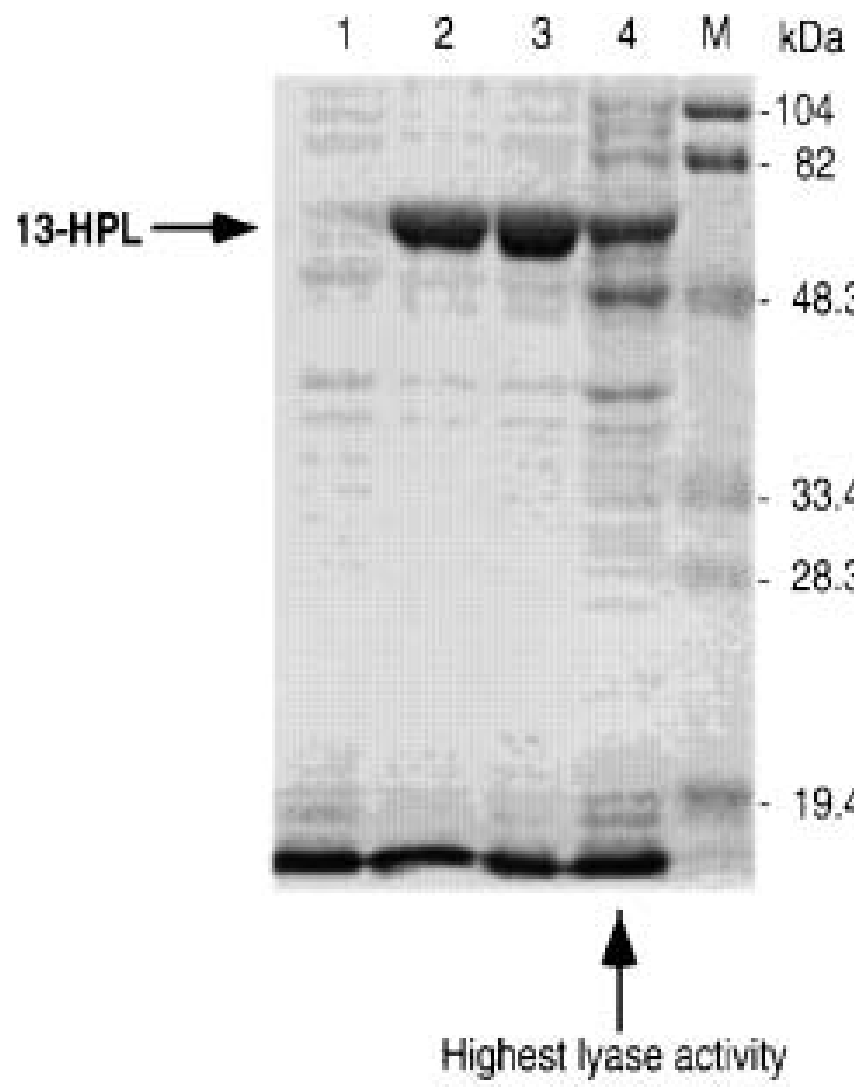

FIG. 3. Sodium dodecyl sulfate-polyacrylamide gel electrophoresis analysis of guava 13-HPL expressed in Escherichia coli (BL21 cells). Lane 1: cells were transformed with pET30 vector alone. In the other lanes, cells were transformed with pET30:13-HPL (containing all four $\mathrm{N}$-terminal methionines) cultured with $\delta$-ALA and IPTG (lane 2), with IPTG only (lane 3), and without $\delta$-ALA and IPTG (lane 4). Molecular weight markers $(M)$ are in the right-hand lane. $\delta$-ALA, $\delta$-aminolevulinic acid; IPTG, isopropyl- $\beta$-D-thiogalactopyranoside; for other abbreviation, see Figure 1.

lower levels of protein but the highest lyase activity when the cells were grown in the absence of $\delta$-ALA and IPTG (Fig. 3, lane 4). By using Emulphogen or cholate detergents, most of the expressed 13-HPL protein failed to solubilize, and the insoluble material was catalytically inactive. This likely reflects the fact that there is a very high basal induction in this system, and the cells are barely capable of handling the expressed protein. Examination of the cells under the microscope revealed many inclusion bodies, with the highest number in cells grown with IPTG. This supports the concept that the bacteria cannot handle the level of expressed protein and the main part of the translated lyase is deposited in inclusion bodies. Using IPTG as a further stimulus results in even lower recovery of correctly folded protein with catalytic activity.

Lyase activity. The four different guava 13-HPL constructs (-Met1, -Met6, -Met9, and -Met13) did not differ markedly in their catalytic activities in the UV assay. Figure 4 illustrates an example with pET30Met1, and also shows the lack of significant activity in the negative control in comparison to the reaction with 13-hydroperoxylinolenic acid. Approximately 10-fold lower rates of reaction were obtained with 13(S)-hy-

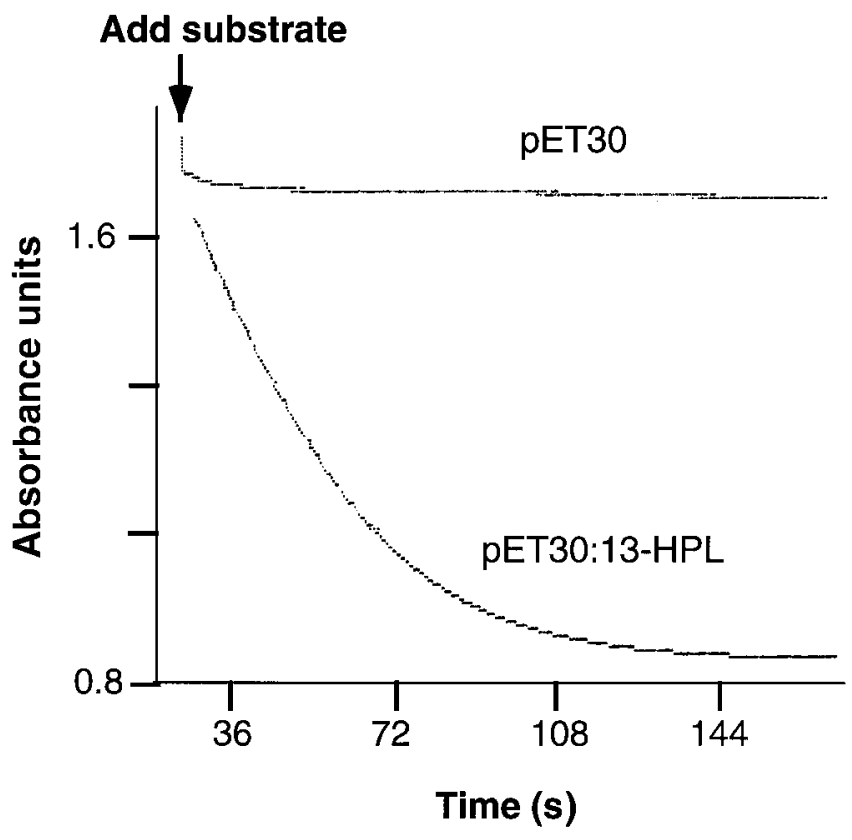

FIG. 4. Spectrophotometric assay of the guava 13-HPL expressed in $E$. coli. Absorbance changes were monitored at $235 \mathrm{~nm}$ in potassium phosphate buffer, $\mathrm{pH}$ 7.6. Comparison of activity of $1 \mu \mathrm{L}$ aliquots of bacterial lysates transformed with pET30 vector alone and with pET30:13-HPL. For abbreviations, see Figures 1 and 3.

droperoxylinoleic acid, 9(S)-hydroperoxylinoleic acid, and 15(S)-hydroperoxyeicosatetraenoic acid.

For HPLC analysis of the nonvolatile products, an aliquot of the sonicated protein preparation containing the 13-HPL was incubated with $\left[1-{ }^{14} \mathrm{C}\right] 13(S)$-hydroperoxylinolenic acid for $1 \mathrm{~min}$ as described in the Experimental Procedures section. Essentially all the substrate was metabolized in the $1 \mathrm{~min}$ of incubation, and the $1-{ }^{14} \mathrm{C}$ label was recovered in a major polar product (Fig. 5) with a retention time expected of the
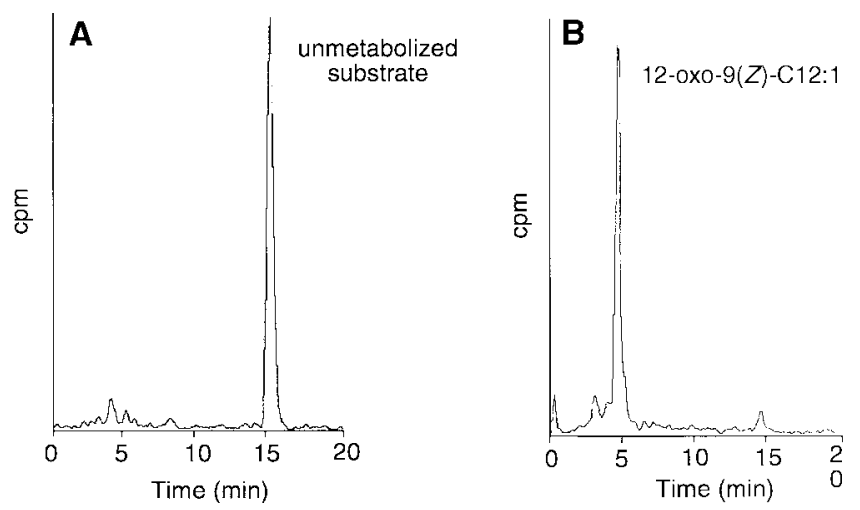

FIG. 5. HPLC analysis of catalytic activity of guava 13-HPL expressed in E. coli. Extracts were incubated with $\left[1-{ }^{14} \mathrm{C}\right] 13(S)$-hydroperoxylinolenic acid, extracted, and aliquots injected on a Beckman Ultrasphere ODS column $(25 \times 0.46 \mathrm{~cm})$ and eluted with a solvent system of methanol/water/glacial acetic acid (77.5:22.5:0.01, by vol) at a flow rate of $1.1 \mathrm{~mL} / \mathrm{min}$. (A) Incubation of extracts of BL21 cells expressing vector pET30 only. (B) Incubation of extracts of BL21 cells expressing pET30:13-HPL. Radioactivity was detected on-line using a Packard FloOne scintillation detector. For abbreviations, see Figures 1 and 3. 

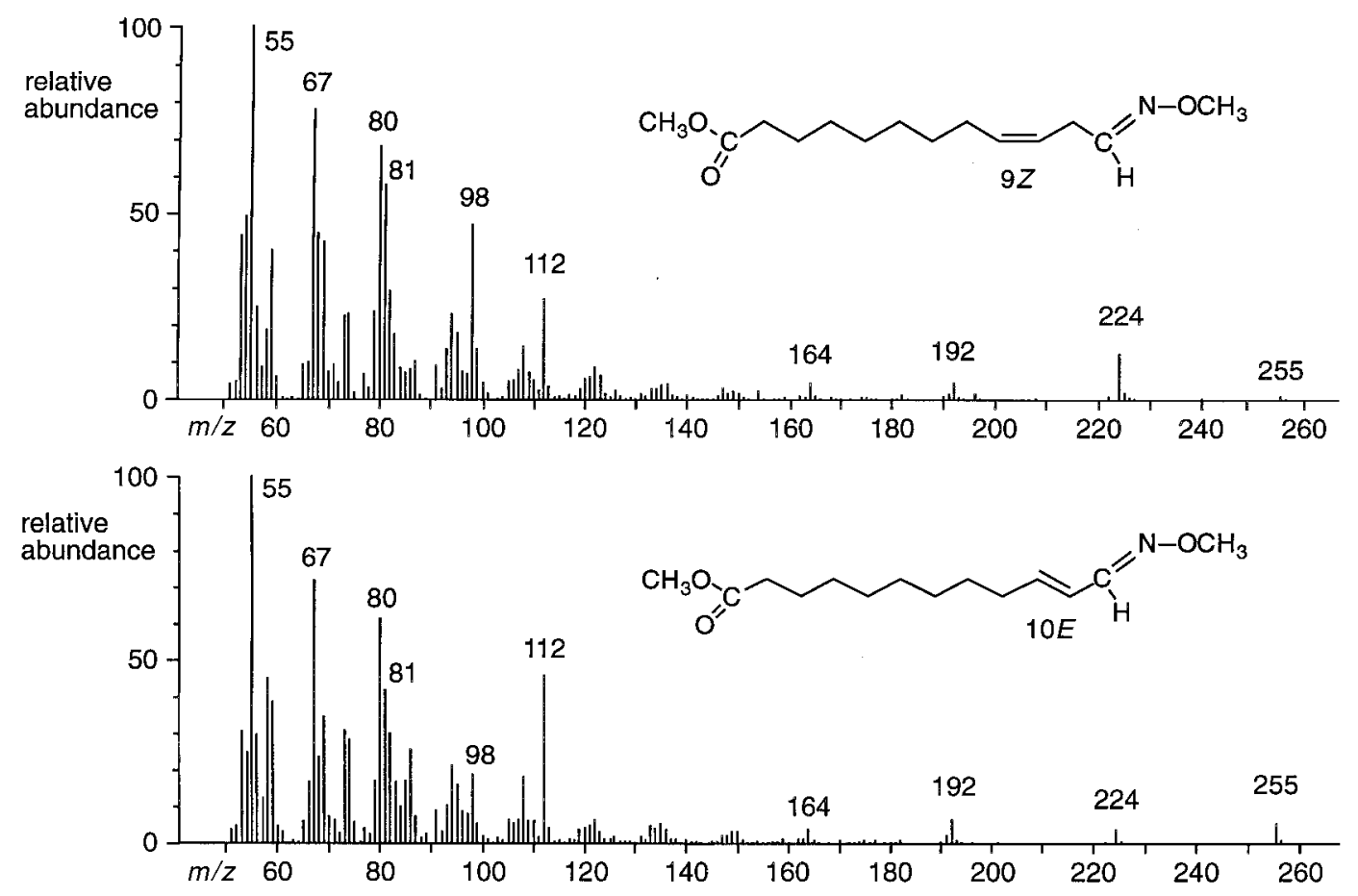

FIG. 6. Electron impact mass spectra of (9Z)-12-oxo-dodecenoic acid formed by reaction of the guava lyase with 13(S)-hydroperoxylinolenic acid and its $10 E$ isomer. The two isomers were resolved by normal-phase HPLC and analyzed as the methyl ester methoxime derivative (top spectrum, 9Z; bottom, 10E). For abbreviation, see Figure 1.

13-HPL-derived aldehyde, 12-oxo-9(Z)-dodecenoic acid. This product, which partly isomerized to the $10 E$ isomer during sample workup, was resolved into the $9 Z$ and $10 E$ isomers by normal-phase HPLC (as described in the Experimental Procedures section). The two isomers were converted to the methoxime methyl ester derivatives and identified by GC-MS analysis (Fig. 6). The methyl (9Z)-12-oxo-dodecenoate methoxime eluted from the GC as a single peak at the retention time approximately of a saturated $\mathrm{C}_{16}$ fatty acid methyl ester; the $10 E$ analog eluted 0.6 min later as a double peak of syn and anti methoxime isomers. The $9 Z$ isomer (assigned based on its featureless UV spectrum, recorded before and after methoxime formation) gave a mass spectrum that was particularly close in appearance to the first reported spectrum of methyl 12-oxo-dodecenoate methoxime (24). The similarity in the mass spectra was noticeable particularly in terms of the pattern of abundances of the higher mass ions $\left[\mathrm{M}^{+} 255\right.$ (1\% abundance), $\mathrm{M}-31$ at $\mathrm{m} / \mathrm{z} 224$ (14\%), and $\mathrm{m} / \mathrm{z} 192$ $(4 \%)$ ], and the relative abundance of certain prominent lower mass ions such as $m / z, 98$ (47\%) and $m / z, 81(54 \%)$. In retrospect, the original spectrum may have been predominantly the $9 Z$ isomer. We assigned the $10 E$ isomer as such on the basis of the characteristics of its UV spectrum: it displayed the expected enone chromophore with $\lambda_{\max } 225 \mathrm{~nm}$ in $\mathrm{MeOH} / \mathrm{H}_{2} \mathrm{O}$ (75:25, vol/vol) and extended conjugation after methoxime formation, producing a broad chromophore with $\lambda_{\max } 239 \mathrm{~nm}$ in $\mathrm{MeOH}$. The mass spectrum of the $10 E$ derivative contained the same ions as in the $9 Z$, but there were different patterns of ion abundances (Fig. 6). For example, $\mathrm{M}^{+}(5 \%$ relative abun- dance) was slightly more prominent than $\mathrm{m} / z 224$ (3\%), whereas $m / z, 98(20 \%)$ and $m / z, 81(39 \%)$ were less prominent than in the $9 \mathrm{Z}$ isomer. This mass spectrum was a good match with another reported spectrum of the $10 E$ isomer (25).

To detect the more volatile aldehyde product, we utilized direct GC-MS analysis of diethyl ether extracts of the reaction of 13-hydroperoxylinolenic acid with the expressed guava enzyme. The GC profile and mass spectrum identified the volatile product formed as 3(Z)-hexenal (Fig. 7).

\section{DISCUSSION}

An initial screening of the levels of 13-HPL in fruits and vegetables pointed to guava as a rich source of this activity. From the subsequent isolation of the protein we found that approximately a 70-fold purification was sufficient to give a homogeneous preparation of the enzyme. Seventyfold enrichment implies a level of about $1-2 \%$ of the protein in the original extract, consistent with guava as an abundant source of 13-HPL. The two bands isolated in the purification process are almost certainly an indication of partial proteolysis or deglycosylation of the higher molecular weight protein. The difference in molecular weight $(2 \mathrm{kD}$ ) between the two forms could be explained if the heavier form is glycosylated by as few as the equivalent of 10 glucose residues. The purification of the 13HPL from tea leaves (11) showed that the enzyme was separated with hydroxylapatite chromatography into two fractions, HPLI and HPLII with molecular weights of 53 and $55 \mathrm{kD}$. For the 13-HPL from green bell pepper fruits, Shibata et al. (12) 


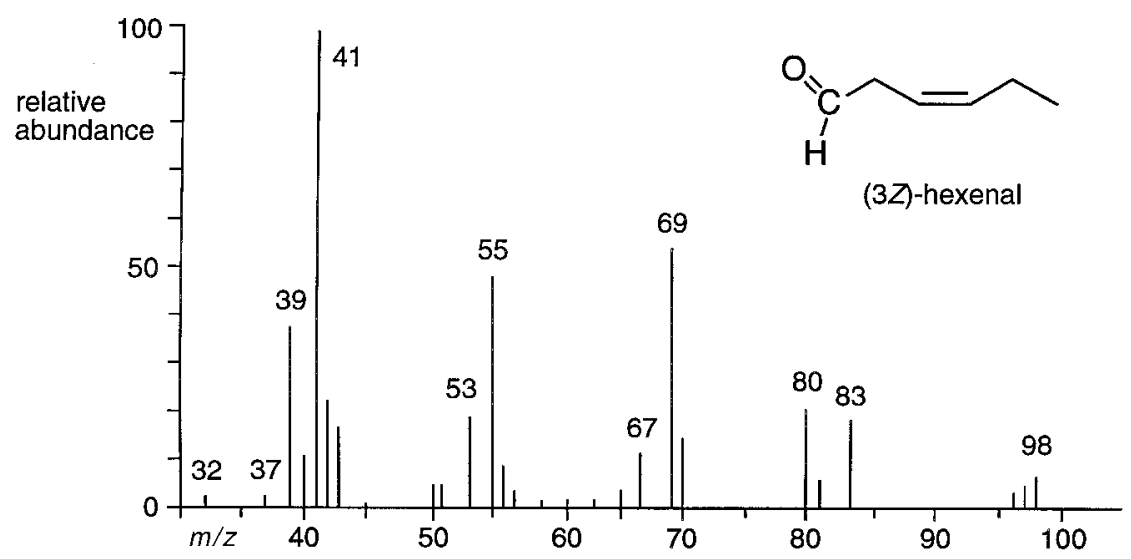

FIG. 7. Electron impact mass spectrum of the volatile $\mathrm{C}_{6}$ product formed by reaction of the guava lyase with $13(S)$-hydroperoxylinolenic acid. The spectrum matches a reference of (3Z)hexenal (Chemical Abstract Service No. 006789-80-6) in the NIST (National Institute of Science and Technology) 75K database on a Hewlett-Packard 5989A mass spectrometer/DOS Chemstation software, entry number 1285 (1992).

showed also that 13-HPL could be resolved into two isoforms by hydroxylapatite chromatography; in this case, both isoforms had molecular masses of $55 \mathrm{kD}$ (12). Similar to the lyases of sunflower (13), the apparent molecular weight of the guava 13-HPL as determined by gel filtration is in the order of $200,000 \mathrm{kD}$, implying a tetrameric structure for the native enzyme. This is in agreement with Olias et al. (10) who reported that 13-HPL from soybean seedlings had a native molecular mass of 240-260 kD and a subunit size of $62 \mathrm{kD}$. However, Shibata et al. (12) proposed that the 13-HPL from green bell pepper fruits is a trimer based on their measurements of the native molecular mass $(170 \mathrm{kD})$ and subunit size $(55 \mathrm{kD})$.

The 13-HPL of guava has a substrate specificity similar to several other reported 13-HPL enzymes. The preferred substrate is $13 S$-hydroperoxylinolenic acid. The corresponding linoleic acid $13 S$-hydroperoxide shows about one-tenth the rate of reaction, and the 9-hydroperoxides also are poor substrates. These results apparently contrast with the original data of lyase activity in guava fruit which indicated excellent recovery of the $\mathrm{C}_{6}$-aldehydes of linoleic and linolenic acids (Table 1). However, a number of factors could account for this difference that relate more to differences in assay conditions. The activity values in fruit comprise recovered products whereas rates of reaction were measured with the expressed enzyme. As the hexenals derived from linolenate are considerably less stable than the saturated product of linoleate, this gives a bias favoring recovery of hexanal. Similarly, changes in enzyme activity due to the different substrate and product concentrations and the different reaction times $(<1 \mathrm{~min}$, vs. $1 \mathrm{~h})$ in the two assays could further influence the results. It is also possible that other isoforms of hydroperoxide lyase might exist in guava. Of the two hydroperoxide lyases purified by Itoh and Vick (13) from sunflower hypocotyl, one resembled the guava and pepper enzymes and a second showed equal reactivity with the C18:2 analog, 13hydroperoxylinoleic acid.

The guava cDNA sequence has about $60 \%$ amino acid identity to the 13-HPL of bell pepper and Arabidopsis, placing it in the same subfamily of cytochrome P450, CYP74B. The enzymes share about 35-40\% identity with the plant AOS, which comprise the CYP74A subfamily. Within the majority of cytochrome P450 families there is a conserved sequence next to the cysteine that forms the proximal ligand to the heme (e.g., Ref. 26). In the CYP74 family, there are some unusual and distinctive sequences around this cysteine (Fig. 8). All reported 13-HPL and AOS enzymes have the sequence Asn-Lys-Gln (NKQ) immediately before the cysteine.

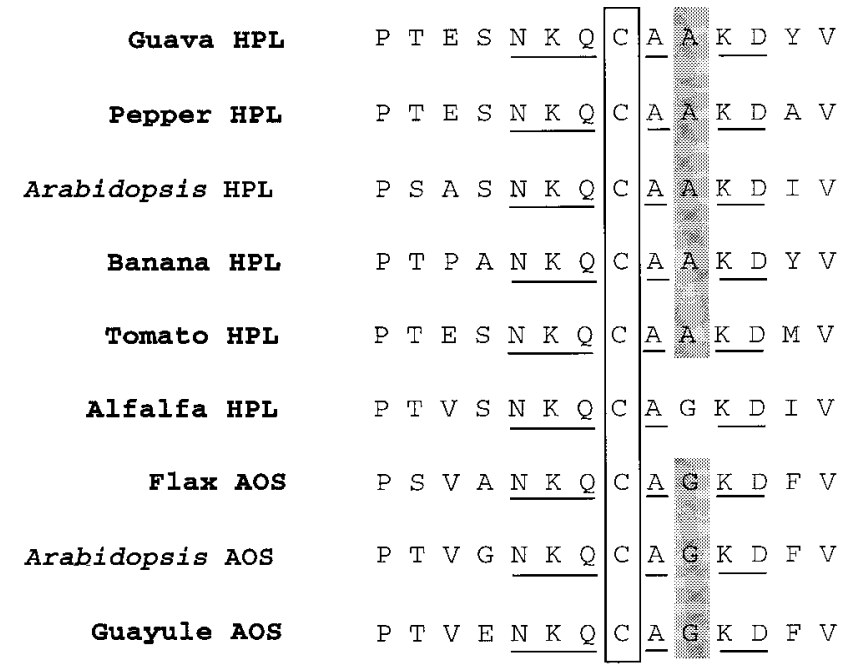

FIG. 8. Alignment of amino acid sequences around the proximal heme ligand. The cysteinyl heme ligand is boxed. The absolutely conserved sequence NKQCA is underlined. The shaded position is usually Ala in 13-HPL, whereas in AOS enzymes the residue is the more typical P450 consensus Gly. The GenBank accession numbers of the sequences, given in parentheses, are for guava HPL (AF239670), bell pepper HPL (U51674), Arabidopsis HPL (AF087932), banana HPL (A65873, the subject of U.S. patent 6,008,034, and patent EP0801133 assigned to Givaudan-Roure International S.A.), alfalfa HPL (AJ249247), flax AOS (U00428), Arabidopsis AOS (AF172727), and guayule AOS (X78166). AOS, allene oxide synthase; for other abbreviation, see Figure 1. 


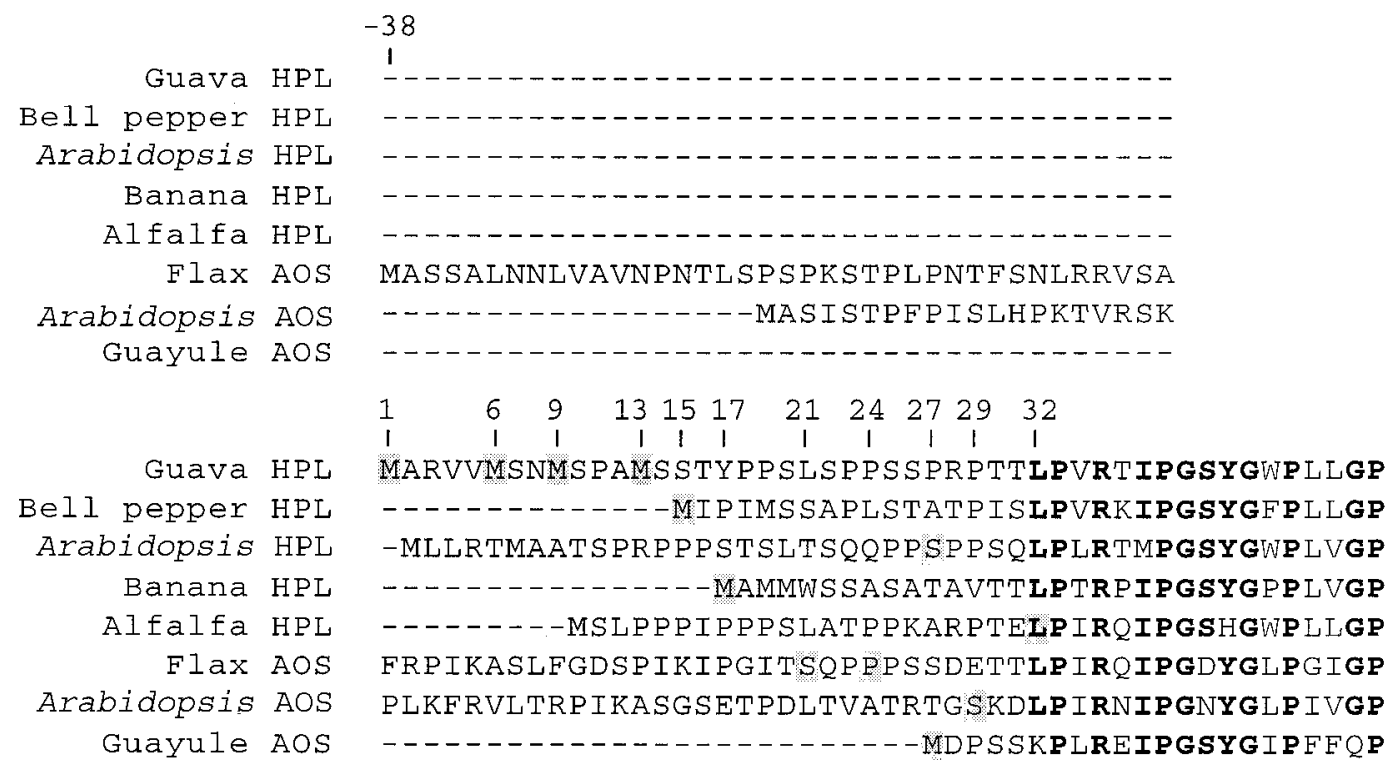

FIG. 9. N-terminal sequence comparison of 13-HPL and AOS enzymes. Comparison of the guava 13-HPL with other CYP74 members. The different enzyme sequences are presented with the conserved residues aligned and shown in bold. The shaded residues indicate the N-terminal start site for the four guava constructs described here and the reported constructs of other enzymes that expressed with catalytic activity $(14,15,22,23,27,31)$. GenBank accession numbers are given in the legend to Figure 8. For abbreviations, see Figures 1 and 8.

Following the cysteine, the AOS (CYP74A) enzymes have the commonly occurring sequence Ala-Gly (Gly in this position is the P450 consensus sequence), giving the overall sequence NKQCAG. On the other hand, the lyases are distinguished by having the sequence Ala-Ala after the Cys. The second alanine, conserved in the lyases, occurs among less than 5\% of all reported cytochromes $\mathrm{P} 450$. It is possible that the CAA sequence gives a structurally significant tilt to the supporting polypeptide under the heme group. Mutation of this second alanine residue would be of interest for future experiments. Figure 8 also illustrates the absolutely conserved Val in the last position of this alignment. This is a very unusual residue in this position, which is normally represented by Gly or Ala in over $95 \%$ of all families of cytochrome P450.

There are remarkable differences in the sequences of the CYP74 family at the N-termini of the proteins (Fig. 9). Certain of the AOS, exemplified in Figure 9 by the flax and Arabidopsis enzymes, have a long presequence that includes a chloroplast transit peptide. In the flaxseed AOS, as deduced by Laudert et al. (27), this includes 21 amino acids that are cleaved to give the mature protein. By contrast, the AOS of guayule has a short N-terminus, more similar to the 13-HPL enzymes. The $\mathrm{N}$-terminal sequence of the guava 13-HPL has some unusual features compared to the HPL of bell pepper and Arabidopsis. There are four methionines in the first 13 amino acids. We tested the effect of deleting these sequences (albeit with an additional $\mathrm{N}$-terminal sequence from the $\mathrm{pET}$ vector still present in each of the expressed proteins). Active lyase was obtained when either the full-length cDNA was expressed, or in the shortened cDNAs with one, two, or three methionines removed. The Arabidopsis 13-HPL could be expressed as cat- alytically active enzyme after deletion of the first 28 amino acids. The shaded residues in Figure 9 indicate the most N-terminal amino acid in constructs that have been successfully expressed with catalytically active enzyme. For the guayule AOS, the CYP74 family member with the shortest known N-terminus, the clear homology to the other enzymes (bold characters in Fig. 9) begins only six amino acids after the initiating methionine. For the CYP74 family, it has yet to be determined what is the shortest possible $\mathrm{N}$-terminus that remains compatible with expression of catalytically active enzyme.

One of the outstanding properties of the AOS enzymes is their very high initial rate of reaction, in the order of 1000 turnovers per second. This contrasts with turnover numbers as low as $1 /$ min for sluggish P450 reactions $(28,29)$, and $\approx 3200 /$ min for the fastest P450-hydroxylations as catalyzed, for example, by the heme domain of $\mathrm{P} 450_{\mathrm{BM} 3}$ (30). The turnover number for HPL has not been reported. We were able to determine a value for the guava 13-HPL following its expression in E. coli. After partial purification of the Histagged enzyme on a nickel affinity column, we obtained a weak UV-visible spectrum that permitted only an approximate quantitation of the enzyme based on the main Soret band at $\approx 400 \mathrm{~nm}$. Nonetheless, the value obtained was sufficient to permit calculation of the turnover number. The initial reaction rates indicate a turnover number for the 13-HPL of approximately 2000/s, a value comparable to the AOS counterparts in the subfamily CYP74A.

\section{ACKNOWLEDGMENTS}

This work was supported by Firmenich S.A., Geneva, Switzerland, and the Kanton of Zürich (KWF Projekt Nr. 2544.1). We thank Dr. 
Fredi Bruhlmann for helpful comments. Use of guava fruit in the commercial production of aliphatic aldehydes and alcohols from natural fatty acid precursors is covered by U.S. Patent number $5,464,761$ assigned to Firmenich S.A.

\section{REFERENCES}

1. Kim, I.S., and Grosch, W. (1981) Partial-Purification and Properties of a Hydroperoxide Lyase from Fruits of Pear, J. Agric. Food. Chem. 29, 1220-1225.

2. Hatanaka, A., Kajiwara, T., and Sekija, J. (1987) Biosynthetic Pathway for C6-Aldehydes Formation from Linolenic Acid in Green Leaves, Chem. Phys. Lipids 44, 341-361.

3. Croft, K.P.C., Jüttner, F., and Slusarenko, A.J. (1993) Volatile Products of the Lipoxygenase Pathway Evolved from Phaseolus vulgaris (L.) Leaves Inoculated with Pseudomonas syringae pv. phaseolicola, Plant Physiol. 101, 13-24.

4. Dickens, J.C., Billings, R.F., and Payne, T.L. (1992) Green Leaf Volatiles Interrupt Aggregation Pheromone Response in Bark Beetles Infesting Southern Pines, Experientia 48, 523-524.

5. Hatanaka, A. (1993) The Biogeneration of Green Odor by Green Leaves, Phytochemistry 34, 1201-1218.

6. Tressl, R., and Drawert, F. (1973) Biogenesis of Banana Volatiles, J. Agric. Food Chem. 21, 560-565.

7. Vick, B.A., and Zimmerman, D.C. (1976) Lipoxygenase and Hydroperoxide Lyase in Germinating Watermelon Seedlings, Plant Physiol. 57, 780-788.

8. Schreier, P., and Lorenz, G. (1982) Separation, Partial Purification and Characterisation of a Fatty Acid Hydroperoxide Cleaving Enzyme from Apple and Tomato Fruits, Z. Naturforsch. C 37, 165-173.

9. Matsui, K., Shibata, Y., Kajiwara, T., and Hatanaka, A. (1989) Separation of 13-Hydroperoxide and 9-Hydroperoxide Lyase Activities in Cotyledons of Cucumber Seedlings, Z. Naturforsch. C 44, 883-885.

10. Olias, J.M., Rios, J.J., Valle, M., Zamora, R., Sanz, L.C., and Axelrod, B. (1990) Fatty Acid Hydroperoxide Lyase in Germinating Soybean Seedlings, J. Agric. Food Chem. 38, 624-630.

11. Matsui, K., Toyota, H., Kajiwara, T., Kakuno, T., and Hatanaka, A. (1991) Fatty Acid Hydroperoxide Cleaving Enzyme, Hydroperoxide Lyase, from Tea Leaves, Phytochemistry 30, 2109-2113.

12. Shibata, Y., Matsui, K., Kajiwara, T., and Hatanaka, A. (1995) Purification and Properties of Fatty Acid Hydroperoxide Lyase from Green Bell Pepper Fruits, Plant Cell Physiol. 36, 147-156.

13. Itoh, A., and Vick, B.A. (1999) The Purification and Characterization of Fatty Acid Hydroperoxide Lyase in Sunflower, Biochim. Biophys. Acta 1436, 531-540.

14. Matsui, K., Shibutani, M., Hase, T., and Kajiwara, T. (1996) Bell Pepper Fruit Fatty Acid Hydroperoxide Lyase Is a Cytochrome P450 (CYP74B), FEBS Lett. 394, 21-24.

15. Bate, N., Sivasankar, S., Moxon, C., Riley, J.M., Thompson, J.E., and Rothstein, S.J. (1998) Molecular Characterization of an Arabidopsis Gene Encoding Hydroperoxide Lyase, a Cytochrome P-450 That Is Wound Inducible, Plant Physiol. 117, 1393-1400.

16. Wan, C.Y., and Wilkins, T.A. (1994) A Modified Hot Borate Method Significantly Enhances the Yield of High-Quality RNA from Cotton (Gossypium hirsutum L.), Anal. Biochem. 223, 7-12.

17. Brash, A.R., Boeglin, W.E., Chang, M.S., and Shieh, B.-H. (1996) Purification and Molecular Cloning of an $8 R$-Lipoxygenase from the Coral Plexaura homomalla Reveal the Related Primary Structures of $R$ - and $S$-Lipoxygenases, J. Biol. Chem. 271, 20949-20957.
18. Hoffman, B.J., Broadwater, J.A., Johnson, P., Harper, J., Fox, B.G., and Kenealy, W.R. (1995) Lactose Fed-Batch Overexpression of Recombinant Metalloproteins in Escherichia coli BL21 (DE3): Process Control Yielding High Levels of Metal-Incorporated Soluble Protein, Prot. Express. Purific. 6, 646-654.

19. Imai, T., Globerman, H., Gertner, J.M., Kagawa, N., and Waterman, M.R. (1993) Expression and Purification of Functional Human 17 Alpha-Hydroxylase/17,20-lyase (P450c17) in Escherichia coli. Use of This System for Study of a Novel Form of Combined 17 Alpha-Hydroxylase/17,20-Lyase Deficiency, $J$. Biol. Chem. 26, 19681-19689.

20. Vick, B.A. (1991) A Spectrophotometric Assay for Hydroperoxide Lyase, Lipids 26, 315-320.

21. Brash, A.R., and Song, W.-C. (1996) Detection, Assay, and Isolation of Allene Oxide Synthase, Methods Enzymol. 272, 250-259.

22. Song, W.-C., Funk, C.D., and Brash, A.R. (1993) Molecular Cloning of an Allene Oxide Synthase: A Cytochrome P450 Specialized for the Metabolism of Fatty Acid Hydroperoxides, Proc. Natl. Acad. Sci. USA 90, 8519-8523.

23. Pan, Z.Q., Durst, F., Werk-Reichhart, D., Gardner, H.W., Camara, B., Cornish, K., and Backhaus, R.A. (1995) The Major Protein of Guayule Rubber Particles Is a Cytochrome P450, J. Biol. Chem. 270, 8487-8494.

24. Zimmerman, D.C., and Coudron, C.A. (1979) Identification of Traumatin, a Wound Hormone, as 12-Oxo-trans-10-dodecenoic Acid, Plant Physiol. 63, 536-541.

25. Hatanaka, A., Kajiwara, T., Sekiya, J., and Fukumoto, T. (1982) Oxygen-Isotope Effect in Enzymatic Cleavage Reaction of 13L-Hydroperoxylinoleic acid to Hexanal and 11-Formyl-cis-9undecenoic Acid, Z. Naturforsch. 37C, 752-757.

26. Brash, A.R., and Song, W.-C. (1995) Structure-Function Features of Flaxseed Allene Oxide Synthase, J. Lipid Mediat. Cell Signal. 12, 275-282.

27. Laudert, D., Pfannschmidt, U., Lottspeich, F., Hollander Czytko, H., and Weiler, E.W. (1996) Cloning, Molecular and Functional Characterization of Arabidopsis thaliana Allene Oxide Synthase (CYP74), the First Enzyme of the Octadecanoid Pathway to Jasmonates, Plant Mol. Biol. 31, 323-335.

28. Guo, Z., Gillam, E.M.J., Ohmori, S., Tukey, R.H., and Guengerich, F.P. (1994) Expression of Modified Human Cytochrome P450 1A1 in Escherichia coli: Effects of 5' Substitution, Stabilization, Purification, Spectral Characterization, and Catalytic Properties, Arch. Biochem. Biophys. 312, 436-446.

29. Gillam, E.M.J., Guo, Z., Ueng, Y.-F., Yamasaki, H., Cock, I., Reilly, P.E.B., Hooper, W.D., and Guengerich, F.P. (1995) Expression of Cytochrome P450 3A5 in Escherichia coli: Effects of 5' Modification, Purification, Spectral Characterization, Reconstitution Conditions, and Catalytic Activities, Arch. Biochem. Biophys. 317, 374-384.

30. Capdevila, J.H., Wei, S., Helvig, C., Falck, J.R., Belosludtsev, Y., Truan, G., Graham-Lorence, S.E., and Peterson, J.A. (1996) The Highly Stereoselective Oxidation of Polyunsaturated Fatty Acids by Cytochrome P450BM-3, J. Biol Chem. 271, 22663-22671.

31. Noordermeer, M.A., van Dijken, A.J.H., Smeekens, S.C.M., Veldink, G.A., and Vliegenthart, J.F.G. (2000) Characterization of Three Cloned and Expressed 13-Hydroperoxide Lyase Isoenzymes from Alfalfa with Unusual N-Terminal Sequences and Different Enzyme Kinetics, Eur. J. Biochem. 267, 2473-2482.

[Received February 25, 2000, and in revised form and accepted April 25, 2000] 